\title{
Economic evaluation for air pollution control technologies selection in power plants processes
}

\author{
${ }^{1}$ S. Soltanali; ${ }^{2 *}$ Z. Shams Hagani; ${ }^{3}$ M. Pazouki Yaftabadi \\ ${ }^{1}$ Department of Chemical Engineering, Faculty of Engineering, Tehran University, Tehran, Iran \\ ${ }^{2}$ Department of Environmental Engineering, Science and Research Branch, Islamic Azad University, Tehran, Iran \\ ${ }^{3}$ Department of Chemical Engineering, University of California, and Chemical Sciences Division, Berkeley, USA
}

Received 15 March 2008; revised 18 May 2008; accepted 10 July 2008

\begin{abstract}
Air quality legislation is entering a transformation phase, shifting the concept of atmospheric emission control towards pollution prevention and emission minimization through a more integrated approach. This transformation, along with public pressure and increased foreign trade, is providing industries with incentives to consider their effect on the environment and to take action where required. To assist industries in determining what air pollution control technologies are best suited to power plants; an assessment of air pollution control technologies used in other countries was carried out. This assessment concluded that the best available technologies for power plants to control air emissions are electrostatic precipitators, low- $\mathrm{NO}_{\mathrm{X}}$ burners, selective catalytic reduction systems and wet flue gas desulphurization (limestone) systems. An assessment of the financial effects associated with air pollution control at power plants was conducted by completing a cost analysis. This analysis demonstrated that by increasing capital expenditure on control technologies by US $\$ 0.25$ billion, the external costs associated with producing electricity can be reduced by almost US\$ 0.5 billion. Formulation of external cost factors and the development of a software database for the information obtained from the different countries, will promote future technology selections.
\end{abstract}

Key words: Environmental engineering group, environmental costing model, equipment costs, life cycle assessment, external cost

\section{INTRODUCTION}

In most large industrial facilities, combustion plants (power plants) are applied according to the owner's demands or requirements as either large utility plants or industrial combustion plants; providing electricity, steam or heat to industrial production processes (Saeedi and Amini, 2007; Patiño-Echeverri et al., 2007). For the purpose of this investigation, the focus was on large utility plants (power stations) that use coal in conventional steam-producing thermal power plants for the generation of electricity. Power plants generate a number of residues, wastes and large amounts of emissions to all environmental media (Rahbar and Kaghazchi, 2005; Thacker, 2006). The most important emissions to air from the combustion of coal are $\mathrm{SO}_{\mathrm{X}}$, $\mathrm{NO}_{x}, \mathrm{CO}$, particulates and greenhouse gases such as carbon dioxide (Javid and Lak, 2007; Soltanali and

\footnotetext{
\*Corresponding Author Email: zgshams@gmail.com

Tel./Fax: +9821 55438077
}

Shams Hagani, 2008; Karbassi et al., 2007). Other substances such as heavy metals, hydrogen fluoride (HF), hydrogen chloride ( $\mathrm{HCl})$, halide compounds, unburned hydrocarbons, non-methane volatile organic compounds and dioxins are emitted in smaller quantities (European IPPC Bureau, 2005; USEPA, 2005, Ardjmand et al., 2005). Good combustion practices and good combustion control along with energy efficiency measures (Karbassi et al., 2008) will aid in the prevention and control of air pollution emissions, regardless of the type of fuel used, the combustion method followed and the size of a facility (European IPPC Bureau, 2005; USEPA, 2005; Abbaspour and Soltaninejad, 2004; Cho and Michelangeli, 2008; Wang et al.,2008). It should also be noted that the type of flue gas desulphurization (FGD) technique used for the prevention and control of $\mathrm{SO}_{\mathrm{x}}$ depends on the type of combustion method, the output, and whether 
the plant is new or existing. Similarly for the prevention and control of $\mathrm{NO}_{\mathrm{x}}$ a combination of combustion modifications and flue gas treatment (FGT) can be used; depending on the output, the fuel used and whether the plant is new or existing (European IPPC Bureau, 2005; Cherp et al., 2003). The most important air emissions that have to be controlled from a coalfired power plant are particulate matter (PM), sulphur oxides $\left(\mathrm{SO}_{\mathrm{X}}\right)$, nitrogen oxides $\left(\mathrm{NO}_{\mathrm{x}}\right)$ and to a lesser extent carbon monoxide (CO), certain heavy metals, hydrogen chloride $(\mathrm{HCl})$ and hydrogen fluoride (HF). For the control of particulates from coal-fired power plants, electrostatic precipitators (ESP) and/or fabric filters can be selected. Both of these control technologies provide a removal efficiency of $99.9 \%$ for particulates, and removal efficiencies of $90 \%$ for heavy metals such as arsenic, cadmium, chromium, lead and nickel (Cooper and Alley, 2002; Giri et al., 2007). Both ESPs and fabric filters are recommended technologies for particulates and heavy metals removal by the UK and the EU and are in use in more than 7 (ESPs) and 12 (fabric filters) records from the RBLC database. For final selection the electrostatic precipitator was chosen as the control technology for particulates and heavy metals removal since the device is not as sensitive to high temperatures as fabric filters, and since ESPs have been proven to work effectively in power plants (Eskom Holdings Limited, 2002). Cyclones are also recommended for PM removal by the UK, EU and by records from the RBLC database, but should only be used as pre-cleaners upstream of the primary collection device; for example, an electrostatic precipitator, where dust loading is high. Controlling $\mathrm{SO}_{\mathrm{X}}$ emissions from coal-fired power plants should, where possible and economically feasible (Shams-Hagani et al., 2007), be controlled first and foremost by switching or changing fuel.This is recommended by the UK, EU and various RBLC records. Flue gas desulphurization (wet, semi-dry and dry) is the most highly recommended control technology for the control of $\mathrm{SO}_{2}$, being recommended by the UK and the EU and is in use in more than 14 RBLC records. Flue gas desulphurization technologies, such as spray dryers, can also effectively remove $\mathrm{HCl}$ and HF. For final selection wet flue gas, desulphurization with limestone was chosen as the control technology for $\mathrm{SO}_{2}$ and possibly $\mathrm{HCl}$ and $\mathrm{HF}$ emissions from coal-fired power plants. This control technology offers the highest removal efficiency (90-
$98 \%$ ) (Cooper and Alley, 2002) and is the preferred technology for coal-fired electric utility power plants (USEPA, 2003a). For the prevention and control of $\mathrm{NO}_{\mathrm{x}}$ a combination of combustion modifications and flue gas treatment (FGT) can be used (European IPPC Bureau, 2005; Hrastel et al., 2007). Low- $\mathrm{NO}_{\mathrm{X}}$ burners were selected as the combustion modification to be used. Low- $\mathrm{NO}_{\mathrm{x}}$ burners are recommended by the UK and the EU and are in use in more than seven RBLC records. Low- $\mathrm{NO}_{\mathrm{x}}$ burners can reduce $\mathrm{NO}_{\mathrm{x}}$ emissions by $40-60 \%$ and can be used on both new and existing facilities (Cooper and Alley, 2002).

The flue gas treatment that was selected is selective catalytic reduction (SCR). A SCR system is the recommended control technology for the UK and the EU and is in use in more than seven RBLC records. SCR systems are the most developed and widely spread FGT technology and can remove $60-90 \%$ of $\mathrm{NO}_{\mathrm{X}}$ from flue gases (Cooper and Alley, 2002). Selective noncatalytic reduction (SNCR) systems are also recommended to a great extent but the removal efficiency is lower $(40-60 \%)$, the operating temperature is higher $\left(900^{\circ} \mathrm{C}-1000^{\circ} \mathrm{C}\right)$ and the technology is not as well developed and wide spread as the SCR (Cooper and Alley, 2002; Chaaban et al., 2004). Good combustion practices and control is the only way to reduce carbon monoxide $(\mathrm{CO})$ emissions from coal-fired power plants. Proper practices and control will ensure complete or near complete combustion, which consequently reduces $\mathrm{CO}$ emissions.

The basis of the study was a hypothetical $3600 \mathrm{MW}$ (six $600 \mathrm{MW}$ units) power plant. The analysis was done over the time span of one production year, assuming 330 days of production, and it was assumed the power plant operates at $85 \%$ capacity on average. It was further assumed that the air pollution control technologies operated at their full design control efficiency.

\section{MATERIALS AND METHODES}

\section{The EEGECOST model}

The EEGECOST model was developed to promote environmental accounting in south Africa. The EEGECOST model (Environmental Engineering Group environmental costing model) is based on the principles of the total cost assessment (TCA) environmental accounting system. The objective of the model is to fully understand the cost significance of environmental and human health related decisions, activities and consequences over the whole life cycle of a product or 
process. The structure of the model and consists of five steps for analysis (De Beer and Friend, 2005): (1) objective statement and scope of analysis, (2) life cycle assessment, (3) cost inventory, (4) impact assessment, and (5) document results and assumptions.

The model is a spreadsheet-based program and consists of pathways that the user must follow in specific analysis. These different pathways depend on the objective statement and scope of analysis, and the amount of data the user needs to acquire (De Beer and Friend, 2005).

Compiling an objective is the first step of the EEGECOST model. This entails a background of the company and provides some informative value to the product or process being considered. The scope of analysis determines the time frame that is desired for the analysis and the type of cost comparison (De Beer and Friend, 2005). The next step of the EEGECOST model is the life cycle assessment (LCA) of the process or product being considered. The LCA is a procedure that is determined by a company's own specific guidelines. Therefore, the model does not support an LCA procedure in itself, but only the output of a relevant LCA is used as input to the model (De Beer and Friend, 2005). The LCA for environmental accounting systems entails coupling a quantitative value to environmental impacts associated with a project by (Little, 2000). Compiling an inventory of relevant energy and material inputs and environmental releases, evaluating the potential environmental and social impacts associated with identified inputs and releases, and interpreting the results to make informed decisions. Coupling a quantitative life cycle assessment to an environmental accounting system provides a comprehensive view of the environmental impacts of a project and a more accurate picture of the true environmental trade-offs, with associated financial effects (USEPA, 2001).

During the third step of the EEGECOST model, output from the LCA of the process or product is allocated to cost types to be used in the environmental cost inventory. The model allocates environmental costs to the following cost types (De Beer and Friend, 2005): Type I: site costs, Type II: corporate costs, Type III: impact costs, Type IV: internal intangible costs, and Type V: external costs. Type I costs are further subdivided in Type I(a) non-recurring site costs and Type I (b) recurring site costs.
After allocation to cost types, the output from the LCA is translated to an economic value. Economic values are calculated by recording/entering all relevant present and future environmental costs and revenues in cost inventory forms. These forms are categorized into the following environmental media groups (De Beer and Friend, 2005): air and climate, wastewater, soil and groundwater, noise and vibration, biodiversity and landscape radiation, and other costs.

Since only the financial effects associated with air pollution and air pollution control was being considered in this cost analysis, use was only made of the air and climate environmental media group.

The final report compiled by the EEGECOST model can be compiled according to a company's specific regulations, incorporating the reported values as given in the costs incurred by type form, the cost types by year form and the cost report form of the model (De Beer and Friend, 2005).

\section{Calculations}

The EEGECOST model was used to study the financial effects of controlling air pollution from a coalfired power plant. The basis of the study was a hypothetical $3600 \mathrm{MW}$ (six $600 \mathrm{MW}$ units) power plant. The analysis was done over the time span of one production year, assuming 330 days of production, and it was assumed the power plant operates at $85 \%$ capacity on average. It was further assumed that the air pollution control technologies operated at their full design control efficiency.

Three different control regimes were analyzed with the aid of the EEGECOST model: Control regime 1: Hypothetical power plant with only control of particulate matter via an electrostatic precipitator (ESP) with $90 \%$ operating efficiency. This was done efficiencies between $90 \%$ and $99 \%$, and newer ESPs between $99 \%$ and 99.9 $\%$ (USEPA, 2003e). Control regime 2: Hypothetical power plant with only particulate matter control in place in the form of a $99.9 \%$ efficient bag house (fabric filter). This was done in order to represent a newer plant with a bag house employed for air pollution control. Control regime 3: Hypothetical power plant with full pollutant control in place in the form of the final selected control technologies: $99.9 \%$ efficient ESP, $60 \%$ efficient low$\mathrm{NO}_{\mathrm{x}}$ burners, $90 \%$ efficient selective catalytic reduction (SCR) system, and $98 \%$ efficient wet flue gas desulphurization (FGD) system with limestone. 
The purpose of the cost analysis was to show that the external costs or damage costs would be greatly reduced if proper air pollution control technologies were utilized. Only the financial effects associated with air pollution and air pollution control were considered in the cost analysis.

Since the costs that were obtained for the cost analysis were not all in $\$$ value for the year 2007, the costs had to be adjusted to compensate for any price increases due to inflation and other factors. Cost adjustments were done using the Marshall and Swift equipment cost index Table 1.) and the following equation (Cooper and Alley, 2002):

$P_{2006}=P_{X} \times \frac{C l_{2006}}{C l_{X}}$

Since the most recent cost index available is for the year 2006, the cost analysis was done by adjusting costs for 2006. In some cases, the capacity of a required piece of equipment differed in capacity of a known piece of equipment with a known price. The following equation was used to adjust costs where necessary (Cooper and Alley, 2002):

$P_{2}=P_{1}\left(C_{2} / C_{1}\right)^{0.6}$

The following costs were obtained from various literature sources and, where required, adjusted using

Eq. (1) and Eq. (2) These costs were then inserted into the EEGECOST model, following the sequential steps of the program.

\section{Equipment Costs}

Equipment costs were obtained by sizing literature costs based on a $3600 \mathrm{MW}$ power plant, using efficiencies as stated.

Table 1: Marshal and Swift equipment cost indices.

\begin{tabular}{ll}
\hline Year & Index $^{*}$ \\
\hline 1988 & 852 \\
1992 & 943.10 \\
1997 & 1052.80 \\
1998 & 1061.90 \\
1999 & 1068.30 \\
2002 & 1104.20 \\
2003 & 1123.60 \\
2004 & 1178.50 \\
2005 & 1244.50 \\
2006 & 1302.30 \\
\hline
\end{tabular}

*Data from Randall, (2007).

\section{Electrostatic precipitator}

For this cost analysis two different electrostatic precipitators (ESPs), an older ESP with $90 \%$ control efficiency and a new ESP with a control efficiency of $99.9 \%$, were used. The purchase cost of an ESP can be estimated as a function of the collection plate area as follows (Cooper and Alley, 2002):

$P=962 A^{0.628}$

The nett plate area can be calculated by using Eq. (4)

(Cooper and Alley, 2002):

$A=\left(-Q / W_{\mathrm{e}}\right) \ln (1-\eta)$

The delivered equipment cost (DEC) can be estimated with Eq. (5) and the total installed cost (TIC) can be estimated with Eq. (6) (Cooper and Alley, 2002):

$\mathrm{DEC}=\mathrm{P} \times 1.18$

$\mathrm{TIC}=\mathrm{DEC} \times 2.22$

From Eq. (4) the nett plate areas for the two ESPs were calculated using a drift velocity of $6 \mathrm{~m} / \mathrm{min}$. and assuming the plate consisted of six $600 \mathrm{MW}$ units, each treating $3333 \mathrm{~m}^{3} / \mathrm{min}$ flue gas(Eskom Holdings Limited, 2003):

$$
\begin{aligned}
& A_{90 \%}=(-3333 / 6) \ln (1-0.90)=127921 \mathrm{~m}^{2}=13769 \mathrm{ft}^{2} \\
& A_{99.9 \%}=(-3333 / 6) \ln (1-0.90)=387364 \mathrm{~m}^{2}=41308 \mathrm{ft}^{2}
\end{aligned}
$$

Since both the $90 \%$ and the $99.9 \%$ ESPs nett plate areas are less $50000 \mathrm{ft}^{2}$; Eq. (3) can be used to calculate the purchase costs as follows:

$\mathrm{P}_{90 \%}=\mathrm{US} \$ 382307$ per $600 \mathrm{MW}$ unit

$\mathrm{P}_{99.9 \%}=\mathrm{US} \$ 762158$ per $600 \mathrm{MW}$ unit

Using equations (5) and (6), the total installed cost (TIC) calculated:

$\mathrm{TIC}_{90 \%}=\mathrm{US} \$ 1001492$ per $600 \mathrm{MW}$ unit

$\mathrm{TIC}_{99.9 \%}=\mathrm{US} \$ 1996548$ per $600 \mathrm{MW}$ unit

For a $3600 \mathrm{MW}$ power plant the total installed cost is:

$\mathrm{TIC}_{90 \%}=\mathrm{US} \$ 6008953$ 
$\mathrm{TIC}_{99.9 \%}=\mathrm{US} \$ 11979287$

Adjusting the 1998 costs to 2006 values, Eq. (4) was used:

$\mathrm{TIC}_{90 \%, 2006}=6008953(1302.3 / 1061.90)=\mathrm{US} \$ 7369300$

$\mathrm{TIC}_{99.9 \%, 2006}=11979287(1302.3 / 1061.90)=\mathrm{US} \$ 14691238$

Unfortunately, estimates for operating costs for ESPs are not widely available. However, one reference stated that the annual operating cost of a unit treating 1416 $\mathrm{m}^{3} /$ min gas was $\$ 220000$ in 1998 (STEP, 2005). This cost was adjusted to a unit treating $200000 \mathrm{~m}^{3} / \mathrm{h}$. (3333 $\mathrm{m}^{3} / \mathrm{min}$ ) flue gas with Eq. (2):

$\mathrm{P}_{\text {operating }}=220000(3333 / 1416)^{0.6}=\mathrm{US} \$ 367740$ per 600 MW unit in 1988.

Adjusting the 1988 operating cost to the 2006 value, Eq. (1) was used:

$\mathrm{P}_{\text {operating, } 2006}=367740(1302.3 / 852)=\mathrm{US} \$ 562100$ per 600 MW unit.

Fabric Filter

The purchase cost of a bag house system (fabric filter) can be estimated as a function of gross cloth area. Eq.(7) was used to calculate the gross cloth area of the bag house system (Cooper and Alley, 2002):

$\mathrm{GCA}=\mathrm{Q} / \mathrm{V}$

From data, a gross cloth area of $58858 \mathrm{ft}^{2}$ for a 600 MW unit was calculated. Since the gross cloth area is greater than $30000 \mathrm{ft}^{2}$ but smaller than $70000 \mathrm{ft}^{2}$, a large shaker bag house was selected and Eqs. (8) to (10) used to estimate the purchase cost of a bag house (Cooper and Alley, 2002):

$$
\begin{aligned}
& \mathrm{BBP}=\mathrm{US} \$ 96230+\mathrm{US} \$ 3.33 \times \mathrm{GCA} \\
& \mathrm{SSA}=\mathrm{US} \$ 51280+\mathrm{US} \$ 1.43 \times \mathrm{GCA} \\
& \mathrm{INS}=\mathrm{US} \$ 26330+\mathrm{US} \$ 0.57 \times \mathrm{GCA}
\end{aligned}
$$

The total purchase cost of the bag house system is the bag house price plus the cost of the bags. Shaker loop top bags were selected and the bag price was estimated with Eq. (11) (Cooper and Alley, 2002):

$\mathrm{BP}=0.63 \times \mathrm{GCA}$
With the gross cloth area available, the bag house price was calculated with Eqs. (8) to (11):

$\mathrm{BBP}=\mathrm{US} \$ 96230+\mathrm{US} \$ 3.33 \times 58858=\mathrm{US} \$ 292226$ per $600 \mathrm{MW}$ unit in 1998,

$\mathrm{SSA}=\mathrm{US} \$ 51280+\mathrm{US} \$ 1.43 \times 58858=\mathrm{US} \$ 135447$ per $600 \mathrm{MW}$ unit in 1998,

$\mathrm{INS}=\mathrm{US} \$ 26330+\mathrm{US} \$ 0.57 \times 58858=\mathrm{US} \$ 59879$ per $600 \mathrm{MW}$ unit in 1998, and

$\mathrm{BP}=0.63 \times 58858=\mathrm{US} \$ 37080$ per $600 \mathrm{MW}$ unit in 1998 .

The total bag house purchase cost is:

$\mathrm{P}=\mathrm{BBP}+\mathrm{SSA}+\mathrm{INS}+\mathrm{BP}=\mathrm{US} \$ 524632$ per $600 \mathrm{MW}$ unit in 1998

The delivered equipment cost (DEC) can be estimated with Eq. (12) and the total installed cost (TIC) can be estimated with Eq. (13) (Cooper and Alley, 2002):

$\mathrm{DEC}=\mathrm{P} \times 1.18$

$\mathrm{TIC}=\mathrm{DEC} \times 2.19$

Using Eq. (12) and (13), TIC = US\$ 1355755

Adjusting the 1998 cost to the 2006 value, Eq. (1) was used:

$\mathrm{TIC}_{2006}=1355755(1302.3 / 1060.90)=\mathrm{US} \$ 1434528$ per $600 \mathrm{MW}$ unit.

Low $N O_{X}$ burners

Low- $\mathrm{NO}_{x}$ burners appear to be very cost effective, yielding $40 \%-60 \%$ reductions at a capital cost of about 6-9 \$/kW (STEP, 2005; Cooper and Alley, 2002). Based on the calculated capital cost of US\$27 million, the capital cost in 2006 was US\$ 33272237.

\section{Selective catalytic reduction system}

The capital costs for selective catalytic reduction (SCR) and selective non-catalytic reduction systems (SNCR) have significantly declined in the last 20 years, due to improved designs and more familiarity with the technology (Cooper and Alley, 2002). The capital cost of a SCR in 1997 was estimated at between 44-66 US\$/ $\mathrm{kW}$ with a 70-80 \% control efficiency (STEP, 2005; Cooper and Alley, 2002), and the operating cost of a 
SCR system in 1997 was estimated between 1.60-3.25 US\$/MWh (STEP, 2005). Based on the calculated capital cost of \$ 198 million, the capital cost in 2006 was US\$ 243 million and with the operating cost calculated at US\$ 59 million, the operating cost in 2006 was US\$ 72 million.

Wet flue gas desulphurization with limestone

The technology of flue gas desulphurization (FGD) systems is now more advanced than it was in the 1970s, and costs have decreased. Nevertheless, FGD systems still represent a huge investment, as much as $20 \%$ of the capital cost of a new coal-fired power plant (Cooper and Alley, 2002). The capital cost for a FGD system can be estimated at between 100-250 US\$/kW and the operating cost at between 20-50 US\$/kW (USEPA, 2003a). Based on the calculated in 2002, capital cost of US\$ 630 million, the capital cost in 2006 was US\$ 7.4 million and with the operating cost calculated at US\$ 126 million, the operating cost in 2006 was US\$ 149 million.

\section{Life cycle assessment (LCA)}

Life cycle assessment data is specific to every plant and every situation. However, since this analysis is based on a hypothetical $3600 \mathrm{MW}$ plant, annual reported data representing a number of power plants was used. Typically, life cycle data is more complete, but for the purpose of this analysis, the annual reported data given in Table 2. was used to represent LCA data for the hypothetical plant. Other inputs to the process, for example coal and electricity, were not available as intrinsic values and the total cost spent on primary energy was used to determine these relevant costs.

The data shown in Table 2 was converted to mass values for one production year. In order to calculate the pollutants emitted for each control regime, the yearly mass values were reduced according to the applicable removal efficiency of the control technologies in place. For Control regime 1 no reductions were applied since it was assumed that the data in Table 2. applies to a power plant with a $90 \%$ efficient ESP already in place.

\section{External costs}

Adjustment of estimated damage costs (Table 3) using Eq. (1):

$$
\mathrm{P}_{\mathrm{SO}, 2006}=6818(1302.3 / 1061.90)=€ 8361.5
$$

Table 2: Annual reported data used in the cost analysis to represent LCA data

\begin{tabular}{lll}
\hline Input & Unit & Number of units \\
\hline water & $\mathrm{L} / \mathrm{kWh}$ & 1.29 \\
Output & Unit & Number of units \\
$\mathrm{PM}$ & $\mathrm{g} / \mathrm{kWh}$ & 0.28 \\
$\mathrm{SO}_{2}$ & $\mathrm{~g} / \mathrm{kWh}$ & 8.22 \\
$\mathrm{NO}_{\mathrm{X}}$ & $\mathrm{g} / \mathrm{kWh}$ & 3.62 \\
$\mathrm{CO}_{2}$ & $\mathrm{~g} / \mathrm{kWh}$ & 0.9 \\
\hline
\end{tabular}

Table 3: Estimated damage costs in 1998 per ton pollutant emitted

\begin{tabular}{ll}
\hline Pollutant & $€ /$ ton of pollutant [1998] \\
\hline $\mathrm{PM}$ & 6818 \\
$\mathrm{SO}_{2}$ & 5736 \\
$\mathrm{NO}_{\mathrm{X}}$ & 140623 \\
$\mathrm{CO}_{2}$ & 139 \\
\hline
\end{tabular}

$$
\begin{aligned}
& \mathrm{P}_{\mathrm{NOx}, 2006}=5736(1302.3 / 1061.90)=€ 7034.56 \\
& \mathrm{P}_{\mathrm{PM}, 2006}=14063(1302.3 / 1061.90)=€ 17246.7 \\
& \mathrm{P}_{\mathrm{CO}, 2006}=139(1302.3 / 1061.90)=€ 170 .
\end{aligned}
$$

\section{Other costs}

\section{Insurance for environmental liabilities}

Insurance for environmental liability includes the annual contribution to insurance against traditional damage to persons, goods and biodiversity caused by dangerous and potentially dangerous activities and, insurance for transportation of hazardous materials (De Beer and Friend, 2005). An amount of US\$ 1.8 million was allocated for pollution control costs, rehabilitation and any future closures based on a 3600 MW power plant for one production year. The EEGECOST model automatically allocates insurance costs as Type II costs.

\section{Provisions for environmental management}

These costs include future expenses related to, for example, remedial activities, equipment repairs and governmental and public hearings that can result due to an accidental event; for example, air emission releases due to control equipment breakdown (De Beer and Friend, 2005). An amount of US\$12.2 million was allocated for non-current liabilities like future pollution control costs and future rehabilitation costs. This cost is based on a $3600 \mathrm{MW}$ power plant for one production year. Any provisions are automatically allocated as Type III costs by the EEGECOST model. 


\section{Research and development}

Research and development accounts for extra expenses related to internal environmental related research and development projects. Research and development costs can be allocated as either Type I or Type II costs, based on the company's own regulations (De Beer and Friend, 2005). For the purpose of this cost analysis $40 \%$ was allocated to Type I costs and $60 \%$ was allocated to Type II costs. An amount of $\$ 0.3$ million was allocated for research and development for a $3600 \mathrm{MW}$ power plant for one production year.

\section{General direct costs}

Direct costs represent direct capital outlay and include raw materials like primary energy and water and any other auxiliary materials that become part of the product. Direct costs can be allocated as either Type I or Type II costs, based on the company's own regulations (De Beer and Friend, 2005). For the purpose of this cost analysis $40 \%$ was allocated to Type I costs and $60 \%$ was allocated to Type II costs. An amount of $\$ 13.6$ million is paid annually for water and an amount of $\$ 139.7$ million is paid annually for primary energy, which includes coal and electricity. A further amount of $\$ 12$ million is paid annually for other materials. These costs were all based on a $3600 \mathrm{MW}$ power plant for one production year.

\section{RESULTS AND DISCUSSION}

The purpose of this cost analysis was to show specifically the financial effects of controlling air pollution. This was done by inserting all aforementioned costs into the EEGECOST model and consequently comparing the external costs (Type V) of the different analyses. Special attention was paid external costs since it was assumed that, apart from the extra expenditure on control equipment; all other costs would stay fairly constant for the different analyses. External costs are furthermore becoming more relevant since these costs are not taken into account when making decisions but are real to members of society (European Commission, 2001). Valuing external costs therefore allows these values to be included and considered during decision making (European Commission, 2001). For control regime 1, a hypothetical $3600 \mathrm{MW}$ power plant was analyzed for one production year. All the costs were inserted into the EEGECOST model and the model automatically assigned the costs to the different cost types. In all analyses, a discount rate of $12 \%$ was used for Type I to IV costs, which are internal to the company, and a discount rate of $3 \%$ for Type $\mathrm{V}$ costs, which are external to the company. It is important to note that in the cost analysis attention was only on the financial effects of air pollution and air pollution control.

The percentage contribution by cost type for a 3600 MW coal-fired power plant for one production year with Control regime 1 is shown in Fig. 1. Type V costs (external costs) contribute $74 \%$, and Type II cost, which is mostly the capital cost of the control equipment, contribute $14 \%$. The external costs seem exaggerated since the only large capital expenditure in the analysis is that of the ESP.

For Control regime 2 the same hypothetical 3600 MW power plant was analyzed, but in this analysis the air pollution control device was a $99.9 \%$ efficient fabric filter (Fig. 2.). There is little difference between Control regime 1 and 2; with an external cost reduction of only $1 \%$. This can be contributed to the fact that the two control devices are fairly similar in efficiency and capital expenditure.

In the last analyses the hypothetical $3600 \mathrm{MW}$ power plant was analyzed with Control regime 3 in place. All the major pollutants are being controlled to some extent, except for carbon dioxide $\left(\mathrm{CO}_{2}\right)$. Fig. 1 shows the percentage contribution by cost type for a $3600 \mathrm{MW}$ coal-fired power plant for one production year with control regime 3 . The external costs are significantly reduced by $64 \%$ if all the major air pollutants are controlled. However, it is also important to note that Type II cost have now increased to $73 \%$.

From Fig. 1. to Fig. 3. the external costs were reduced by almost $64 \%$ by controlling all the major air pollutants through increasing the capital expenditure on control technologies with $58 \%$. The percentage contribution of the external costs are so high since these costs have to be carried by individuals, the environment and society every year, while the capital expenditure on air pollution control technologies are depreciated over their depreciable life. Furthermore, only the effect of air pollution and controlling air pollution are included in the analyses.

\section{CONCLUSION}

The future of air quality legislation is standing on the verge of a major transformation, shifting the concept of atmospheric emission control towards pollution prevention and emission minimization 


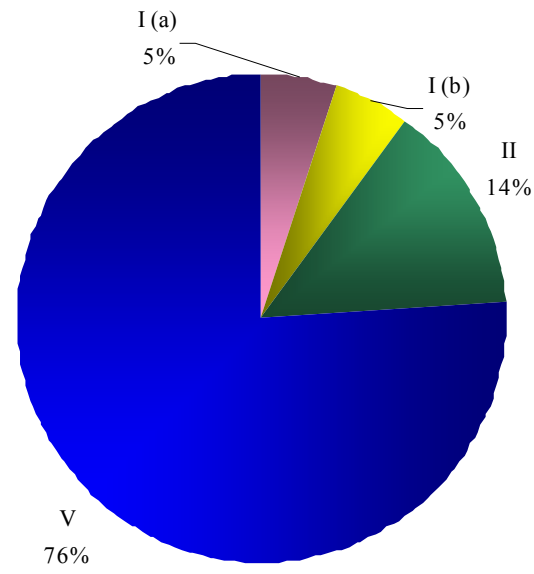

Fig. 1: Percentage contribution of the various cost types associated with a coal- fired power plant controlling only particulate matter via an electrostatic precipitator

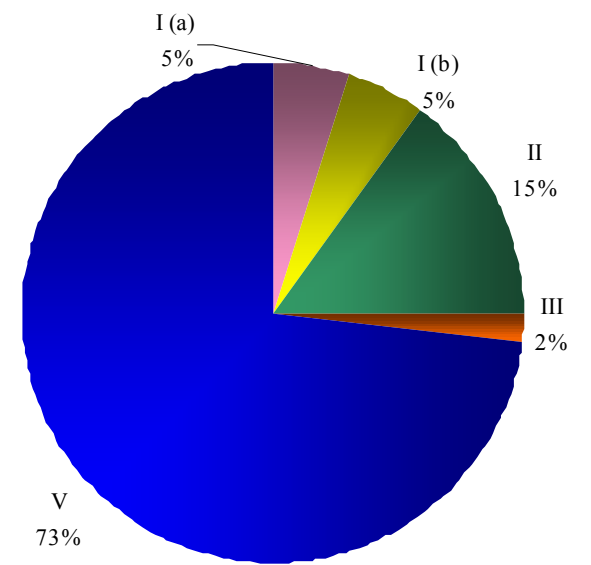

Fig. 2: Percentage contribution of the various cost types associated with a coal- fired power plant controlling only particulate matter via a bag filter

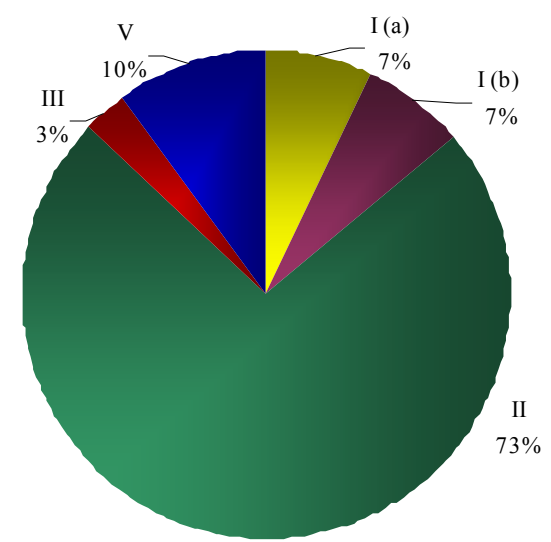

Fig. 3: Percentage contribution of the various cost types associated with a coal- fired power plant controlling particulate matter, sulphur oxides and nitrogen oxides 
through a more integrated approach. This transformation, along with increased foreign trade, is providing industries with incentives to consider their effect on the environment and to take action where required. The knowledge and experience gained from other countries in this regard is a valuable asset and was used to determine what technologies are best suited to power plants, gasification and refining processes. Therefore, with the information sourced from other countries the following conclusions were made regarding the best available technologies or techniques suited to power plants: an electrostatic precipitators for particulates and heavy metal control, low- $\mathrm{NO}_{\mathrm{x}}$ burners for reducing nitrogen oxide formation in the boiler or furnace, selective catalytic reduction systems for $\mathrm{NO}_{\mathrm{X}}$ control, and wet flue gas desulphurization with limestone for $\mathrm{SO}_{\mathrm{x}}$ control. A cost analysis conducted for a power plant with selected air pollution control technologies in place demonstrated that the selected technologies worked well to reduce the external cost associated with producing electricity by almost $\$ 0.5$ billion. This reduction in external cost was brought about by increasing the capital expenditure on control technologies by $\$ 0.25$ billion. Even though the cost of controlling air pollution is high, it resulted in a considerable reduction in external cost that normally has to be carried by the environment, society and individuals.

\section{Nomenclature}

\begin{tabular}{|c|c|}
\hline A & nett plate area $\left[\mathrm{ft}^{2}\right]$ \\
\hline BBP & basic bag house price [US\$, 1998] \\
\hline $\mathrm{BP}$ & bag price [US\$, 1998] \\
\hline $\mathrm{C}_{1}$ & capacity of known equipment \\
\hline $\mathrm{C}_{2}$ & capacity of new equipment \\
\hline $\mathrm{Cl}_{x}$ & cost index for relevant year $x$ \\
\hline $\mathrm{Cl}_{2006}$ & cost index for 2006 \\
\hline GCA & gross cloth area $\left[\mathrm{ft}^{2}\right]$ \\
\hline INS & insulation add on [US\$, 1998] \\
\hline 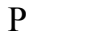 & \\
\hline purch & cost, [US\$, 1998] \\
\hline $\mathrm{P}_{x}$ & cost index in year $x$ \\
\hline $\mathrm{P}_{1}$ & price of known equipment \\
\hline $\mathrm{P}_{2}$ & price of new equipment \\
\hline $\mathrm{P}_{2006}$ & cost in 2006 \\
\hline Q & volumetric flow rate $\left[\mathrm{ft}^{3} / \mathrm{min}\right.$ or $\left.\mathrm{m}^{3} / \mathrm{min}.\right]$ \\
\hline SSA & stainless steel add on [US\$, 1998] \\
\hline $\mathrm{V}$ & maximum filtering velocity $[\mathrm{ft} / \mathrm{min}]$. \\
\hline $\mathrm{W}_{\mathrm{e}}$ & drift velocity [ft / min or $\mathrm{m} / \mathrm{min}]$. \\
\hline
\end{tabular}

\section{Greek Symbols \\ $\eta \quad$ collection efficiency}

\section{REFERENCES}

Abbaspour, M.; Soltaninejad, A., (2004). Design of an environmental assessment model on the effect of vehicle emission in greater Tehran on air pollution with economic sensitivity. Int. J. Environ. Sci. Tech., 1 (1), 27-38.

Ackerman, K. V.; Sundquist, E. T., (2008). Comparison of two U.S. power plant carbon dioxide emissions data sets. Environ. Sci. Technol. 2008, 42, 5688-5693.

Ardjmand, M.; Safekordi, A.; Farjadfard, S., (2005). Simulation of biofilter used for removal of air contaminants (ethanol). Int. J. Environ. Sci. Tech., 2 (1), 69-82.

Chaaban, F. B.; Mezher, T.; Ouwayjan, M., (2004). Options for emissions reduction from power plants: An economic evaluation, Int. J. Elec. Power, 26 (1), 57-63.

Cherp, A.; Kopteva, I.; Mnatsakanian, R., (2003). Economic transition and environmental sustainability: Effects of economic restructuring on air pollution in the Russian Federation, J. Environ. Manage., 68 (2), 141-151.

Cho, S.; Michelangeli, D. V., (2008). Modeling study of the effects of the coagulation kernel with van der Waals forces and turbulence on the particle size distribution. Int. J. Environ. Sci. Tech., 5 (1), 1-10.

Cooper, C. D.; Alley F. C., (2002). Air Pollution Control A Design Approach. $3^{\text {rd }}$ Ed. Waveland Press, Inc., Illinois.

De Beer, P. J.; Friend, J. F. C., (2005). Environmental accounting: a management tool for enhancing corporate environmental and economic performance. Ecological Economics. Available at: http://www.sciencedirect.com.

Eskom; Holdings Limited, (2002). GFS 0005 generation's commitment to the environment. Available at: http:// www.eskom.co.za/live/content.php? Item ID $=32 \&$ $\underline{\text { Revision }=e n / 0}$.

European commission, (2001). A research project of the European commission: The ExternE Project, Available at: http://www.extern.info/.

European IPPC BUREAU, (2005). Reference document on best available techniques for large combustion plants. Integrated Pollution Prevention and Control Bureau draft publication, European Commission, May 2005, Seville.

Giri, D.; Murthy, V. K.; Adhikary, P. R.; Khanal, S. N., (2007). Estimation of number of deaths associated with exposure to excess ambient $\mathrm{PM}_{10}$ air pollution. Int. J. Environ. Sci. Tech., 4 (2), 183-188.

Hrastel, I.; Gerbec, M.; Stergarsek, A., (2007). Technology optimization of wet flue gas desulfurization process, Chem. Eng. Tech., 2 (30), 220-233.

Javid, A. H.; Lak, P., (2007). Dynamic optimization of air treatment systems for fundries. Int. J. Environ. Res., 1 (4), 347-353.

Karbassi, A. R.; Abduli, M. A.; Mahin Abdollahzadeh, E., (2007). Sustainability of energy production and use in Iran. Energ. Policy., 35 (10), 5171-5180.

Karbassi, A. R.; Abduli, M. A.; Neshastehriz, S., (2008). Energy saving in Tehran International Flower Exhibition's building. Int. J. Environ. Res., 2 (1), 75-86.

Little, A. D., (2000). Total cost assessment methodology: Internal managerial decision making tool. Centre for waste 
reduction technologies, American Institute of Chemical Engineers publication, New York.

Patiño-Echeverri, D.; Morel, B.; Apt, J.; Chen, C., (2007). Should a coal fired power plant be replaced or retrofitted?, Environ. Sci. Tech., 41 (23), 7980-7986.

Rahbar, S. M.; Kaghazchi, T., (2005). Modeling of packed absorption tower for volatile organic compounds emission control. Int. J. Environ. Sci. Tech., 2 (3), 207-215.

Randall, W., (2007). Process equipment cost estimating by ratio and proportional. Available at: http:// www.PDHcenter.com.

Saeedi, M.; Amini, H. R., (2007). Chemical, physical, mineralogical, morphology and leaching characteristics of a thermal power plant air heater washing waste. Int. J. Environ. Res., 1 (1), 74-79.

Shams Hagani, Z.; Soltanali, S.; Binner, M. L., (2007). Economic evaluation of soil remediation using supercritical fluid. Int. J. Environ. Res., 1 (4), 302-306.

STEP, (2005). Report on economic analysis, Princeton University, Available at: http://www.wws.princeton.edu/step/ ch4.pdf

Soltanali, S.; Shams Hagani, Z., (2008). Modeling of air stripping from volatile organic compounds in biological treatment processes. Int. J. Environ. Sci. Tech., 5 (3), 353 360 .

Thacker, P. D., (2006). Getting religious about air pollution, Environ. Sci. Technol. A., 40 (17), 5167-5168.

USEPA, (2001). LCA 101 - Introduction to LCA, United States Environmental Protection Agency and Science Applications International Corporation, Available at: http:/ /www.epa.gov/ORD/NRMRL/lcaccess/lca101.html.

USEPA, (2003). Air pollution control technology fact sheet: flue gas desulphurization (FGD) - wet, Available at: http:// www.epa.gov/ttn/catc/products.html\# aptecfacts spray dry and dry scrubbers.

USEPA, (2003). Air pollution control technology fact sheet: dry electrostatic precipitator-wire-pipe type, Available at: http://www.epa.gov/ttn/catc/products.html\#aptecfacts.

USEPA, (2005). Technology transfer network clean air technology centre RACT/BACT/LAER clearinghouse, Available at: http://cfpub.epa.gov/rblc/cfm/basic search.cfm. Wang, H. L.; Hao, Z. P.; Zhuang, Y. H.; Wang, W.; Liu, X. Y., (2008). Characterization of inorganic components of sizesegregated particles in the flue gas of a coal-fired power plant, Energ. Fuel., 22 (3), 1636-1640.

\section{AUTHOR (S) BIOSKETCHES}

Soltanali, S., M.Sc., Department of Chemical Engineering, University of Tehran, Tehran, Iran.

Email: sssoltan@gamil.com

Shams Hagani, Z., M.Sc., student, Department of Environmental Science, Graduate School of the Environment and Energy, Science and Research Branch, Islamic Azad University, Tehran, Iran. Email: zgshams@gmail.com

Pazouki Yaftabadi, M., Ph.D., student of Department of Chemical Engineering, University of California, and Chemical Sciences Division, Berkeley, USA. Email: m.yaftabadi@gmail.com

This article should be referenced as follows:
Soltanali, S.; Shams Hagani, Z.; Pazouki Yaftabadi, M., (2008). Economic evaluation for air pollution control
technologies selection in power plants processes. Int. J. Environ. Sci. Tech.,5 (4), 555-564.

